\title{
Phosphorus forms in leaves and their relationships with must composition and yield in grapevines
}

\author{
Rogério Piccin (1), Rafael da Rosa Couto(2), Roque Júnior Sartori Bellinaso(1), Luciano Colpo Gatiboni(3), \\ Lessandro De Conti( ${ }^{(1)}$, Lucas Antonio Telles Rodrigues ${ }^{(1)}$, Luiza Michelon Somavilla ${ }^{(1)}$, \\ Matheus Severo de Souza Kulmann(1) and Gustavo Brunetto(1)
}

\begin{abstract}
(1)Universidade Federal de Santa Maria, Departamento de Solos, Avenida Roraima, no 1.000, Camobi, CEP 97105-900 Santa Maria, RS, Brazil. E-mail: piccinagro@gmail.com, roquejunior_bellinaso@hotmail.com, lessandrodeconti@gmail.com, lucasatr2009@hotmail.com, luiza_somavilla@hotmail.com, matheuskulmann@hotmail.com, brunetto.gustavo@gmail.com (2)Universidade Federal de Santa Catarina, Rodovia Admar Gonzaga, no 1346, Itacorubi, CEP 88034-000 Florianópolis, SC, Brazil. E-mail: rrccouto@hotmail.com (3)Universidade do Estado de Santa Catarina, Avenida Luis Camões, № 2.090, CEP 88520-000 Lages, SC, Brazil. E-mail: luciano.gatiboni@udesc.br
\end{abstract}

Abstract - The objective of this work was to evaluate phosphorus forms in grape leaves and their relationships with must composition and yield in grapevines grown in a Typic Hapludalf with different available P contents. Two experiments were carried out with Vitis vinifera cultivars, one with 'Tannat' and the other with 'Cabernet Franc' grapes. Experiment 1 consisted of two vineyards of 'Tannat', with the following P content in the soil: $\mathrm{V} 1,11.8 \mathrm{mg} \mathrm{kg}^{-1} \mathrm{P}$; and V2, $34.6 \mathrm{mg} \mathrm{kg}^{-1} \mathrm{P}$. Experiment 2 consisted of two vineyards of 'Cabernet Franc', with the following P content in the soil: V1, $16.0 \mathrm{mg} \mathrm{kg}^{-1} \mathrm{P}$; and $\mathrm{V} 2,37.0 \mathrm{mg} \mathrm{kg}^{-1} \mathrm{P}$. Leaves were collected at flowering (FL) and veraison (V), and, after their preparation, $\mathrm{P}$ forms were evaluated. Yield and must composition were assessed. The highest yield was observed in V2 of experiment 1 and in V2 of experiment 2. Total P content and P forms in leaves at FL and V have no relationship with yield parameters; however, total $\mathrm{P}$ content in leaves has a relationship with anthocyanin content in the must of 'Tannat' grapevines. Therefore, $\mathrm{P}$ fractionation in leaves predicts neither grapevine yield nor must composition.

Index terms: Vitis vinifera, chemical fractionation of $\mathrm{P}$ in the tissue, grape production, must analysis, phosphorus fertilization.

\section{Formas de fósforo em folhas e suas relações com a composição do mosto e a produção em videiras}

Resumo - O objetivo deste trabalho foi avaliar as formas de fósforo em folhas e suas relações com a composição do mosto e a produção em videiras cultivadas em um Argissolo Vermelho distrófico típico, com diferentes teores de $\mathrm{P}$ disponível. Dois experimentos foram realizados com cultivares de Vitis vinifera, um com uvas 'Tannat' e outro com 'Cabernet Franc'. O experimento 1 consistiu de dois vinhedos de 'Tannat', com os seguintes teores de fósforo no solo: $\mathrm{V} 1,11,8 \mathrm{mg} \mathrm{kg}^{-1} \mathrm{de} \mathrm{P}$; e V2, 34,6 $\mathrm{mg} \mathrm{kg}^{-1} \mathrm{de}$ P. O experimento 2 consistiu de dois vinhedos de 'Cabernet Franc', com os seguintes teores de fósforo no solo: V1, 16,0 mg kg-1 de P; e $\mathrm{V} 2,37,0 \mathrm{mg} \mathrm{kg}^{-1}$ de P. Coletaram-se as folhas ao florescimento (FL) e ao início da maturação (IM), e, após a preparação delas, analisaram-se as formas de P. A produtividade e a composição do mosto foram avaliadas. A maior produtividade foi observada no V2 do experimento 1 e no V2 do experimento 2. O teor total de $\mathrm{P}$ e suas formas nas folhas ao FL e IM não apresentam relação com os parâmetros produtivos; no entanto, o teor de P total nas folhas apresenta relação com o teor de antocianinas no mosto de videiras 'Tannat'. Portanto, o fracionamento de $\mathrm{P}$ nas folhas não prediz a produtividade da videira nem a composição do mosto.

Termos para indexação: Vitis vinifera, fracionamento químico de $\mathrm{P}$ no tecido, produção de uva, análise do mosto, adubação fosfatada.

\section{Introduction}

The region of Campanha Gaúcha - located in the Pampa Biome, in Rio Grande do Sul (RS) state -, is incorporated to the grape production system, and shows sandy soils with low organic matter content, and low natural nutrient availability (Brunetto et al., 2013). Therefore, nutrient application, such as phosphorus $(\mathrm{P})$, is required in the pre-planting and in the production fertilization. Sandy soils have low P buffering capacity (Brunetto et al., 2013), and as the P doses established by the recommendation systems cover broad classes of 
clay content, they are not suitable for soils with low P sorption capacity (Schmitt et al., 2014).

In grapevine fertilization, $P$ requirements and doses are established based on the total $\mathrm{P}$ content of leaves collected at veraison and on yield expectation (Brunetto et al., 2015). This procedure comes from the belief that increased $\mathrm{P}$ content available in the soil indicates an increase of $\mathrm{P}$ content within the plant, which is diagnosed by analyzing leaves, since it is an annual organ, with intense cellular division, and increased dry matter production during the vegetative growth and production stages (Lorensini et al., 2015).

However, total $\mathrm{P}$ content in grapevine leaves does not always have a relationship with grape yield (Tecchio et al., 2006; Brunetto et al., 2009), or even with must composition. This may occur because leaves used for total $\mathrm{P}$ analysis are collected at the veraison, which is a period of small emission of young roots that are more active in absorbing water and nutrients, including P. At the same time, grapevine leaves show little cell division and increased dry matter production in this period, thus, not acting as $\mathrm{P}$ sinks (Tecchio et al., 2007). Furthermore, $P$ dilution may happen in leaves, due to the redistribution to other organs such as the clusters, which at this time have an increased dry matter production and are therefore nutrient sinks (Zambrosi et al., 2012).

Therefore, the collection of leaves at flowering seems to be more appropriate, as at this stage the grapevines have an intense emission of young roots. This may increase the absorption of soil $\mathrm{P}$ and $\mathrm{P}$ accumulation in the leaves, which may help the diagnosis and analysis of $\mathrm{P}$ content in the leaves, and its relationships with yield and must composition (Tecchio et al., 2007). Additionally, the lack of relationship between $\mathrm{P}$ content in leaves and yield and must composition may be attributed to the analysis of total nutrient content in the tissue. This occurs because plants can absorb and accumulate $\mathrm{P}$ above the required amounts in growth organs (Veneklaas et al., 2012; Noack et al., 2014). Consequently, it would be more appropriate to analyze the biochemical $\mathrm{P}$ forms in the tissues (Veneklaas et al., 2012), from which we could further infer about the use of the nutrient. Still, the accumulation of $\mathrm{P}$ forms in the diagnostic tissue of organs, such as leaves, can be changed according to the soil-P availability, and to the time of tissue collection; however, no similar work was found on vines in the literature.
The objective of this work was to evaluate $\mathrm{P}$ forms in grape leaves and their relationship with yield and must composition, in grapevines grown in a Typic Hapludalf with different contents of available P.

\section{Materials and Methods}

The experiments were carried out from August 2014 to March 2015, in vineyards located in the Campanha Gaúcha region, in Santana do Livramento, RS ( $\left.30^{\circ} 48^{\prime} 51^{\prime \prime} \mathrm{S}, 55^{\circ} 27^{\prime} 22^{\prime \prime} \mathrm{W}\right)$. The soil is a Argissolo Vermelho distrófico arênico (Santos et al., 2013) - Typic Hapludalf (Soil Survey Staff, 2010). The relief in the vineyards is slightly undulated with a $12 \%$ slope approximately. Physical and chemical characteristics of the four vineyard soils are shown in the Table 1. The climate is humid subtropical Cfa, according to the Köppen-Geiger classification, which is characterized by mild temperatures, and rain with little variation throughout the year. The average annual rainfall is approximately $1,600 \mathrm{~mm}$. Paspalum notatum, Desmodium affine, and Lolium multiflorum predominated between the rows of grapevines. These plants were mowed every 21 days, during the production period, and residues deposited on the soil surface. The vineyards were irrigated using drippers twice a week, from November trough January, totaling the addition of $22 \mathrm{~mm}$ water per week.

The study consisted of two experiments. Experiment 1 was conducted in two vineyards (V1 and V2) of Tannat cultivar (Vitis vinifera L.) with different contents of available $\mathrm{P}$ in the soil (extracted by Mehlich 1, $\left.\mathrm{HCl} 0.05 \mathrm{~mol} \mathrm{~L}^{-1} \mathrm{H}_{2} \mathrm{SO}_{4}+0.0125 \mathrm{~mol} \mathrm{~L}^{-1}\right)$. The V1 soil, cultivated with 'Tannat', contained $11.8 \mathrm{mg} \mathrm{kg}^{-1} \mathrm{P}$, and the V2 soil had $34.6 \mathrm{mg} \mathrm{kg}^{-1} \mathrm{P}$. Experiment 2 was conducted in two vineyards (V1 and V2) cultivated with Cabernet Franc cultivar (Vitis vinifera L.). The V1 soil with 'Cabernet Franc' consisted of $16.0 \mathrm{mg} \mathrm{kg}^{-1}$ $\mathrm{P}$, and the $\mathrm{V} 2$ soil had $37.0 \mathrm{mg} \mathrm{kg}^{-1} \mathrm{P}$. In the experiment $1, \mathrm{~V} 1$ was installed in 2004, and V2 in 2003. In the experiment 2, V1 was installed in 1996, and V2 in 1999. Grapevines of the two experiments were grafted on SO4 rootstock (Vitis berlandieri x Vitis riparia), on a spur pruned cordon system, at a density of 2,525 plants per hectare $(1.20 \times 3.30 \mathrm{~m})$. Winter pruning was mixed; two sticks were left per plant, with eight buds per stick, and eight spurs per plant, with three buds per spur, totaling 40 buds per plant. Both experiments were carried out in randomized block designs with 
three replicates. Each replicate consisted of five plants, and the three central grapevines were evaluated. During the experiments, the plants were subjected to fertilizer applications (except for P) of $40 \mathrm{~kg} \mathrm{~N} \mathrm{ha}^{-1}$ (urea source), and $20 \mathrm{~kg} \mathrm{~K}_{2} \mathrm{O} \mathrm{ha}^{-1}$ ( $\mathrm{KCl}$ source). Before

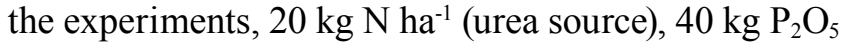
ha $^{-1}$ (triple superphosphate source), and $40 \mathrm{~kg} \mathrm{~K}_{2} \mathrm{O}$ ha $^{-1}$ ( $\mathrm{KCl}$ source) were applied every two years. The nutrient doses were defined based on parameters established for grapevine cultivation, according to Tedesco et al. (2004).

Ten full leaves opposite to the first cluster were collected from each plant, at flowering (FL) in October 2014, when $50 \%$ of the flowers were open. The same procedure was carried out at veraison (V) in December 2014, when $50 \%$ of berries changed color, which is a stage equivalent to color change of the berries (Baillod \& Baggiolini, 1993). Leaves were dried and ground in a Willey type mill. The tissue was passed through a $2 \mathrm{~mm}$ mesh sieve and reserved. One part of the tissue was used to determine total $\mathrm{P}\left(\mathrm{P}_{\text {TOTAL }}\right)$, and the other part, to analyze $\mathrm{P}$ forms in the tissue, according to the methodology proposed by Casali et al. (2011). The obtained forms of $\mathrm{P}$ were: total soluble $\mathrm{P}$ in acid $\left(\mathrm{P}_{\mathrm{ST}}\right)$; inorganic soluble $\mathrm{P}$ in acid $\left(\mathrm{P}_{\mathrm{SI}}\right)$; organic soluble $\mathrm{P}$ in acid $\left(\mathrm{P}_{\mathrm{SO}}\right)$, by the difference between $\mathrm{P}_{\mathrm{ST}}$ and $\mathrm{P}_{\mathrm{SI}}$; lipid $\mathrm{P}\left(\mathrm{P}_{\mathrm{LIP}}\right) ; \mathrm{P}$ associated with $\mathrm{RNA}\left(\mathrm{P}_{\mathrm{RNA}}\right) ; \mathrm{P}$

Table 1. Chemical and physical properties at the $0-0.20 \mathrm{~m}$ soil depth of a Typic Hapludalf, in the vineyards 1 and 2, in experiments 1 ('Tannat' grapes) and 2 ('Cabernet Franc' grapes).

\begin{tabular}{|c|c|c|c|c|}
\hline \multirow[t]{2}{*}{ Soil property } & \multicolumn{2}{|c|}{ Experiment 1} & \multicolumn{2}{|c|}{ Experiment 2} \\
\hline & $\mathrm{V} 1^{(4)}$ & $\mathrm{V} 2^{(5)}$ & $\mathrm{V} 1^{(6)}$ & $\mathrm{V} 2^{(7)}$ \\
\hline Clay, pipette method $\left(\mathrm{g} \mathrm{kg}^{-1}\right)$ & 10 & 15 & 10 & 13 \\
\hline Silt, pipette method $\left(\mathrm{g} \mathrm{kg}^{-1}\right)$ & 12 & 17 & 19 & 14 \\
\hline Sand, pipette method $\left(\mathrm{g} \mathrm{kg}^{-1}\right)$ & 78 & 68 & 71 & 73 \\
\hline Organic matter ${ }^{(1)}\left(\mathrm{g} \mathrm{kg}^{-1}\right)$ & 14 & 9 & 8 & 14 \\
\hline $\mathrm{pH}$ in water $(1: 1 \text { ratio })^{(2)}$ & 5.3 & 6.5 & 6.4 & 6.2 \\
\hline Exchangeable $\mathrm{Ca}^{(2)}\left(\mathrm{cmol}_{\mathrm{c}} \mathrm{dm}^{-3}\right)$ & 1.4 & 1.9 & 1.3 & 3.2 \\
\hline Exchangeable $\mathrm{Mg}^{(2)}\left(\mathrm{cmol}_{\mathrm{c}} \mathrm{dm}^{-3}\right)$ & 0.8 & 0.6 & 0.4 & 1.0 \\
\hline Exchangeable $\mathrm{Al}^{(2)}\left(\mathrm{cmol}_{\mathrm{c}} \mathrm{dm}^{-3}\right)$ & 0 & 0 & 0 & 0 \\
\hline Available $\mathrm{P}^{(3)}\left(\mathrm{mg} \mathrm{dm}^{-3}\right)$ & 11.8 & 34.6 & 16 & 37 \\
\hline Exchangeable $\mathrm{K}^{(3)}\left(\mathrm{mg} \mathrm{dm}^{-3}\right)$ & 100 & 84 & 60 & 124 \\
\hline Cation exchange capacity at $7.0 \mathrm{pH}$ & 4.4 & 3.7 & 3 & 5.9 \\
\hline Base saturation (\%) & 68.1 & 73.6 & 62.3 & 76.4 \\
\hline
\end{tabular}

(1)Determined according to Tedesco et al. (1995). (2) Extracted by KCl $1 \mathrm{~mol}$ $\mathrm{L}^{-1}$ (Tedesco et al., 1995). ${ }^{(3)}$ Extracted by Mehlich-1 (Tedesco et al., 1995). ${ }^{(4)} \mathrm{V} 1$, vineyard 1 of 'Tannat' grapes $\left(11.8 \mathrm{mg} \mathrm{P} \mathrm{kg}^{-1}\right) .{ }^{(5)} \mathrm{V} 2$, vineyard 2 of 'Tannat' grapes (34.6 mg P kg-1 $).{ }^{(6)} \mathrm{V} 1$, vineyard 1 of 'Cabernet Franc' grapes (16 mg P kg-1). ${ }^{(7)} \mathrm{V} 2$, vineyard 2 of 'Cabernet Franc' grapes (37 $\left.\mathrm{mg} \mathrm{P} \mathrm{kg}^{-1}\right)$. associated with DNA $\left(\mathrm{P}_{\mathrm{DNA}}\right)$; and residual $\mathrm{P}\left(\mathrm{P}_{\mathrm{RES}}\right)$. The determination and quantification of all $\mathrm{P}$ forms was done according to Murphy \& Riley (1962), in a UVvisible spectrophotometer.

The number of clusters per plant was counted at harvest in January 2015. All clusters were harvested and weighed using a digital scale to determine yield (Y). Eight clusters per plant were reserved. Subsequently, the number of berries counted in each cluster to determine the number of berries (NB). Five hundred berries, from the top, middle, and bottom of eight clusters, were collected and weighed to determine the weight of 100 berries (WB). Berries of each treatment reserved at harvest were separated into two parts, stored, and refrigerated. Part of the berries were crushed by hand, and the following procedures were carried out: analysis of total soluble solids (TSS) ( ${ }^{\circ}$ Brix), using a manual refractometer; $\mathrm{pH}$ analysis, using bench top $\mathrm{pH}$ meter at $20^{\circ} \mathrm{C}$; titratable acidity (TA), by chemical titration with sodium hydroxide at $0.1 \mathrm{~mol} \mathrm{~L}^{-1}$ solution, and bromothymol blue as an indicator; total polyphenols (PP), by reaction with Folin Ciocalteu, and absorbance reading in a UV-VIS spectrophotometer, using $765 \mathrm{~nm}$ wavelength (Singleton \& Rossi, 1965); total anthocyanin (AC), using $80 \mathrm{~mL}$ ethanol-water (70:30) as extractor, and subsequent addition of $1 \mathrm{~mol} \mathrm{~L}^{-1} \mathrm{HCl}$ to adjust the $\mathrm{pH}$ to 2.0; and absorbance, which was measured in a spectrophotometer at $540 \mathrm{~nm}$ (Teixeira et al., 2009). The content of $\mathrm{P}$ in the must (PM) was determined by sulfuric digestion and hydrogen peroxide.

Data were subjected to analysis of variance using the Sisvar software (Universidade Federal de Lavras, Lavras, MG, Brazil), the means were compared by the Scott-Knott test, based on significance levels lower than $5 \%(\mathrm{p}<0.05)$. The proportional value of each $\mathrm{P}$ form in leaves, in each experiment, and at both collection times, as well as yield and composition of must, were compared by multivariate principal component analysis (PCA), based on the correlation between the variables.

\section{Results and Discussion}

In the experiment 1 , with 'Tannat' grapes, the largest values of yield, WB, PP, and $\mathrm{AC}$ were found in $\mathrm{V} 2$, which contained high available $\mathrm{P}$ content (Table 2) and, also, higher $\mathrm{pH}$ than that of $\mathrm{V} 1$ (Table 1). The parameters NB and $\mathrm{pH}, \mathrm{TSS}, \mathrm{PM}$, and TA in the must did not differ statistically between the two vineyards. 
In the experiment 2, with 'Cabernet Franc' grapes, the largest values of yield, $\mathrm{NB}, \mathrm{pH}$, and $\mathrm{PM}$ in the must were found in $\mathrm{V} 2$, with high $\mathrm{P}$ content available in the soil (Table 2). However, the highest value of TA was found in the must of $\mathrm{V} 1$, which had lower P content available in the soil. PP and $\mathrm{AC}$ values did not differ between $\mathrm{V} 1$ and V2, which is opposite to that observed in experiment 1 .

The highest yields (in both experiments) in grapevines of the vineyards with high $\mathrm{P}$ content available in soil, as well as WB in experiment 1 , and NB in experiment 2, can be attributed, at least in part, to the greater P supply to the roots of plants and, consequently, to the greater $\mathrm{P}$ absorption (Ozdemir et al., 2010) because the contents of most other nutrients in the soil tended to be similar among the vineyards (Table 1). As a consequence of a higher $\mathrm{P}$ absorption, the maintenance of $\mathrm{P}$ content within plants is expected, as well as a decrease of assimilate translocations and energy for the formation of lateral roots and root hairs (Vance et al., 2003). Thus, the energy and carbon skeletons that would be used for root formation are used for fruit production (Batista et al., 2011). This occurs because $\mathrm{P}$ has a structural function, participating in various metabolic processes, such as energy transfer, nucleic acid synthesis, glucose, respiration, membrane synthesis and stability, activation and deactivation of enzymes, redox reactions and carbohydrate metabolism (Vance et al., 2003).

The highest TA values found in the must of V1 grapevines, with medium $\mathrm{P}$ content available in soil of the experiment 2, can be attributed to a greater accumulation of malic acid and tartaric acid in the must (Tecchio et al., 2006; Teixeira et al., 2009). The $\mathrm{pH}$ and TA values observed in the must of $\mathrm{V} 1$ and $\mathrm{V} 2$ of the experiment 1 fall between 3.3 and 3.6 for $\mathrm{pH}$, and

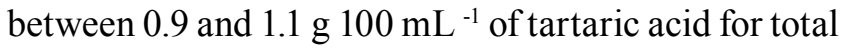
acidity (TA), which corroborates the results reported by Sato et al. (2011). The $\mathrm{pH}$ and TA values found in the present work favor the qualitative wine composition because they provide a beneficial antimicrobial effect, as they reduce the bacteria proliferation in the wine, and improve the organoleptic characteristics of the wines (Teixeira et al., 2009).

The contents of TSS were not affected by P content available in the soil, in the two experiments, although yield was higher in V2 of the experiment 1, and in V2 of the experiment 2. TSS is important for the preparation of wine, since it provides precursors for the synthesis of organic acids, phenolic compounds, and aroma compounds. It also determines the concentration of alcohol after fermentation because for $1 \mathrm{ABV}$ of alcohol, $1,8^{\circ}$ Brix is necessary (Sato et al., 2011).

The contents of PP and AC in the must of 'Tannat' grapevines were higher in V2 of the experiment 1 , unlike what was expected, because high values of available $\mathrm{P}$ in the soil, and later in plant organs, can inhibit the enzyme activities, such as chalcone synthase and phenylalanine ammonia-lyase (Hilbert et al., 2003). Besides controlling the color of the wine, AC also play an important role for protection protection of the berry, due to its antioxidant activity.

In the experiment $1, \mathrm{P}_{\mathrm{TOTAL}}$ content and $\mathrm{P}_{\mathrm{SI}}, \mathrm{P}_{\mathrm{LIP}}, \mathrm{P}_{\mathrm{RNA}}$, and $\mathrm{P}_{\mathrm{DNA}}$ forms in leaves did not statistically differ

Table 2. Yield, number of berries (NB) per cluster, weight of 100 berries (WB), pH, and values of total soluble solids (TSS), titratable acidity (TA), total polyphenols (PP), anthocyanins (AC), and P in the must (PM) of grapevines of experiments 1 and $2^{(1)}$.

\begin{tabular}{|c|c|c|c|c|c|c|}
\hline \multirow[t]{2}{*}{ Must parameter } & \multicolumn{3}{|c|}{ Experiment 1} & \multicolumn{3}{|c|}{ Experiment 2} \\
\hline & $\mathrm{V} 1^{(2)}$ & $\mathrm{V} 2^{(3)}$ & CV (\%) & $\mathrm{V} 1^{(4)}$ & $\mathrm{V} 2^{(5)}$ & $\mathrm{CV}(\%)$ \\
\hline Yield $\left(\mathrm{kg} \mathrm{ha}^{-1}\right)$ & $5,420.33 b$ & $9,847.50 \mathrm{a}$ & 16.30 & $6,767.00 \mathrm{~b}$ & $13,275.53 a$ & 14.48 \\
\hline Number of berries per cluster (NB) & $108.67 \mathrm{a}$ & $114.83 \mathrm{a}$ & 20.72 & $54.67 \mathrm{~b}$ & $91.50 \mathrm{a}$ & 16.96 \\
\hline WB $(g)$ & $140.32 b$ & $172.13 \mathrm{a}$ & 11.57 & $151.05 \mathrm{a}$ & $138.48 \mathrm{a}$ & 12.67 \\
\hline $\mathrm{pH}$ & $3.56 \mathrm{a}$ & $3.58 \mathrm{a}$ & 2.41 & $3.77 \mathrm{~b}$ & $3.95 \mathrm{a}$ & 2.81 \\
\hline $\operatorname{TSS}\left({ }^{\circ} \mathrm{Brix}\right)$ & $18.40 \mathrm{a}$ & $18.73 \mathrm{a}$ & 3.46 & $17.80 \mathrm{a}$ & $18.03 \mathrm{a}$ & 3.81 \\
\hline TA (g $100 \mathrm{~mL}^{-1}$ in tartaric acid) & $1.07 \mathrm{a}$ & $1.04 \mathrm{a}$ & 4.49 & $0.76 \mathrm{a}$ & $0.53 b$ & 3.73 \\
\hline $\mathrm{PP}\left(\mathrm{mg} \mathrm{L}^{-1}\right.$ in gallic acid $)$ & $8,861.72 b$ & $12,592.18 \mathrm{a}$ & 17.40 & $6,056.57 \mathrm{a}$ & $6,193.47 \mathrm{a}$ & 19.52 \\
\hline $\mathrm{AC}\left(\mathrm{mg} \mathrm{L}^{-1}\right.$ in malvidin $)$ & $2,419.07 b$ & $3,257.35 \mathrm{a}$ & 16.94 & $781.19 \mathrm{a}$ & $787.60 \mathrm{a}$ & 15.70 \\
\hline $\mathrm{PM}\left(\mathrm{mg} \mathrm{kg}^{-1}\right)$ & $1,453.33 \mathrm{a}$ & $1,801.83 \mathrm{a}$ & 10.68 & $1,633.88 \mathrm{~b}$ & $2,077.69 \mathrm{a}$ & 11.56 \\
\hline
\end{tabular}

${ }^{(1)}$ Means followed by equal letters, lowercase in the lines for the same experiment, did not differ by the Scott-Knott test, at $5 \%$ probability. ${ }^{(2)} \mathrm{V} 1$, vineyard 1 of 'Tannat' grapes $\left(11.8 \mathrm{mg} \mathrm{P} \mathrm{kg}^{-1}\right) .{ }^{(3)} \mathrm{V} 2$, vineyard 2 of 'Tannat' grapes $\left(34.6 \mathrm{mg} \mathrm{P} \mathrm{kg}^{-1}\right) .{ }^{(4)} \mathrm{V} 1$, vineyard 1 of 'Cabernet Franc' grapes $\left(16 \mathrm{mg} \mathrm{P} \mathrm{kg}^{-1}\right) .{ }^{(5)} \mathrm{V} 2$, vineyard 2 of 'Cabernet Franc' grapes ( $\left.37 \mathrm{mg} \mathrm{P} \mathrm{kg}^{-1}\right)$. CV, coefficient of variation. 
between V1 and V2, at FL of 'Tannat' grapevines, unlike $\mathrm{P}_{\mathrm{SO}}$ and $\mathrm{P}_{\mathrm{RES}}$, which were higher in plant leaves of V2 (Table 3). At V, $\mathrm{P}_{\text {TOTAL }}$ content and $\mathrm{P}_{\mathrm{SI}}, \mathrm{P}_{\mathrm{SO}}, \mathrm{P}_{\text {LIP }}$, $\mathrm{P}_{\mathrm{RNA}}, \mathrm{P}_{\mathrm{DNA}}$, and $\mathrm{P}_{\mathrm{RES}}$ forms in leaves did not statistically differ between V1 and V2. Considering only $\mathrm{P}_{\text {TотаL, }}$ the 'Tannat' grapevines were efficient in absorbing the necessary $\mathrm{P}$ from the soil, even in the vineyard with lower $\mathrm{P}$ content, unlike that observed for 'Cabernet Franc' grapevines. $\mathrm{P}_{\text {TOtAL }}$ content and $\mathrm{P}_{\mathrm{SI}}, \mathrm{P}_{\mathrm{SO}}, \mathrm{P}_{\text {LIP, }}$ $\mathrm{P}_{\mathrm{RNA}}$, and $\mathrm{P}_{\mathrm{RES}}$ forms were higher, at FL, in leaves of $\mathrm{V} 1$ and V2 grapevines, in comparison to values observed at the veraison. At FL, 'Cabernet Franc' grapevines in the experiment 2 showed higher levels of $\mathrm{P}_{\text {TOTAL }}$, Psr, and $\mathrm{P}_{\mathrm{SO}}$ in the leaves of plants of V2 (Table 3). Values of $\mathrm{P}_{\mathrm{LIP}}, \mathrm{P}_{\mathrm{RNA}}, \mathrm{P}_{\mathrm{DNA}}$, and $\mathrm{P}_{\mathrm{RES}}$ did not differ statistically between the vineyards. At $\mathrm{V}$, only $\mathrm{P}_{\mathrm{SI}}$ was higher in leaves of grapevines of V2. In V1 and V2, the levels of $\mathrm{P}_{\mathrm{LIP}}$ and $\mathrm{P}_{\mathrm{RES}}$ were higher in leaves collected at FL, in comparison to $\mathrm{V}$. The contents of $\mathrm{P}_{\mathrm{TOTAL}}$ and $\mathrm{P}_{\mathrm{SO}}$ were higher only in leaves collected in V2 at FL, in comparison to those of the veraison.
The highest $\mathrm{P}_{\mathrm{SI}}$ content in leaves of the grapevines grown in soil with high available $\mathrm{P}$, at FL, in both experiments, can be attributed to a higher $\mathrm{P}$ supply to the roots and, thus, greater $\mathrm{P}$ absorption. The absorbed $\mathrm{P}$ may have been transported to the leaves, which have intensive cell division, where it is preferably stored in the vacuole (Veneklaas et al., 2012).

The reduction of $\mathrm{P}_{\mathrm{TOTAL}}, \mathrm{P}_{\mathrm{SI}}, \mathrm{P}_{\mathrm{SO}}, \mathrm{P}_{\mathrm{LIP}}, \mathrm{P}_{\mathrm{RNA}}$ and $\mathrm{P}_{\mathrm{RES}}$ levels in leaves of 'Tannat' grapevines both in V1 and $\mathrm{V} 2$ of the experiment 1 , collected at V, may have occurred because of the production increase of green shoot mass, which promotes the dilution of $\mathrm{P}$ forms (Zambrosi et al., 2012). However, the highest content of $\mathrm{P}_{\mathrm{RNA}}$ in leaves of $\mathrm{V} 1$ and $\mathrm{V} 2$ of the experiment 1 , collected at FL, in comparison to $\mathrm{V}$, possibly occurred because part of the absorbed $\mathrm{P}$ was rapidly used for protein synthesis. $\mathrm{P}_{\mathrm{RNA}}$ content is correlated with organ growth rate, due to increased protein production in response to a greater availability of $\mathrm{P}$ in the soil. Protein content can also be regarded as a storage form of $\mathrm{P}$ in cells, since $\mathrm{P}$ contained in $\mathrm{P}_{\mathrm{RNA}}$ form can be

Table 3. Phosphorus forms in grapevine leaves of V1 and V2 of experiment 1, and V1 and V2 of experiment 2, grown at different $\mathrm{P}$ contents available in the soil, and collected at flowering (FL) and veraison (V) ${ }^{(1)}$.

\begin{tabular}{|c|c|c|c|c|c|c|c|}
\hline \multirow{3}{*}{$\begin{array}{l}\text { Phenological } \\
\text { stage }\end{array}$} & \multirow[t]{3}{*}{$\mathrm{P}$ form } & \multicolumn{3}{|c|}{ Experiment 1} & \multicolumn{3}{|c|}{ Experiment 2} \\
\hline & & $\mathrm{V} 1^{(2)}$ & $\mathrm{V} 2^{(3)}$ & \multirow{2}{*}{$\begin{array}{l}\mathrm{CV} \\
(\%)\end{array}$} & \multirow{2}{*}{\multicolumn{2}{|c|}{ 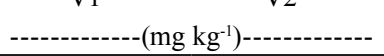 }} & \multirow{2}{*}{$\begin{array}{l}\mathrm{CV} \\
(\%)\end{array}$} \\
\hline & & \multicolumn{2}{|c|}{----------( $\left(\mathrm{mg} \mathrm{kg}^{-1}\right)----\cdot-\cdot----$} & & & & \\
\hline Flowering & Soluble inorganic $\mathrm{P}\left(\mathrm{P}_{\mathrm{SI}}\right)$ & $2,861.0 \mathrm{aA}$ & $2,584.5 \mathrm{aA}$ & 7.2 & $1,705.7 \mathrm{bA}$ & $2,302.0 \mathrm{aA}$ & 14.0 \\
\hline Veraison & Soluble inorganic $\mathrm{P}\left(\mathrm{P}_{\mathrm{SI}}\right)$ & $1,732.1 \mathrm{aB}$ & $1,832.7 \mathrm{aB}$ & 8.5 & $1,517.7 \mathrm{bA}$ & $1,955.2 \mathrm{aA}$ & 15.1 \\
\hline $\mathrm{CV}(\%)$ & & 9.1 & 10.2 & - & 10.3 & 9.7 & - \\
\hline Flowering & Soluble organic $\mathrm{P}\left(\mathrm{P}_{\mathrm{SO}}\right)$ & $619.6 \mathrm{bA}$ & $970.8 \mathrm{aA}$ & 9.3 & $375.9 \mathrm{bA}$ & $585.6 \mathrm{aA}$ & 7.0 \\
\hline Veraison & Soluble organic $\mathrm{P}\left(\mathrm{P}_{\mathrm{SO}}\right)$ & $291.3 \mathrm{aB}$ & $331.7 \mathrm{aB}$ & 8.2 & $478.9 \mathrm{aA}$ & $332.3 \mathrm{aB}$ & 8.1 \\
\hline CV (\%) & & 7.7 & 8.3 & - & 15.2 & 10.3 & - \\
\hline Flowering & Lipid $\mathrm{P}\left(\mathrm{P}_{\text {LIP }}\right)$ & $625.7 \mathrm{aA}$ & $591.0 \mathrm{aA}$ & 11.0 & $608.6 \mathrm{aA}$ & $612.1 \mathrm{aA}$ & 11.4 \\
\hline Veraison & Lipid P $\left(\mathrm{P}_{\text {LIP }}\right)$ & $389.0 \mathrm{aB}$ & $389.0 \mathrm{aB}$ & 11.2 & $402.2 \mathrm{aB}$ & $355.4 \mathrm{aB}$ & 9.3 \\
\hline CV (\%) & & 10.5 & 13.2 & - & 8.6 & 12.4 & - \\
\hline Flowering & $\mathrm{P}$ associated with RNA $\left(\mathrm{P}_{\mathrm{RNA}}\right)$ & $547.2 \mathrm{aA}$ & $658.6 \mathrm{aA}$ & 14.6 & $617.8 \mathrm{aA}$ & $676.2 \mathrm{aA}$ & 15.2 \\
\hline Veraison & $P$ associated with RNA $\left(\mathrm{P}_{\mathrm{RNA}}\right)$ & $416.1 \mathrm{aB}$ & $467.6 \mathrm{aB}$ & 19.0 & $494.7 \mathrm{aA}$ & $483.8 \mathrm{aA}$ & 16.4 \\
\hline $\mathrm{CV}(\%)$ & & 14.3 & 11.9 & - & 10.2 & 11.5 & - \\
\hline Flowering & $\mathrm{P}$ associated with RNA $\left(\mathrm{P}_{\mathrm{DNA}}\right)$ & $31.4 \mathrm{aA}$ & $48.4 \mathrm{aA}$ & 12.6 & $40.2 \mathrm{aA}$ & $42.4 \mathrm{aA}$ & 4.9 \\
\hline Veraison & $\mathrm{P}$ associated with RNA $\left(\mathrm{P}_{\mathrm{DNA}}\right)$ & $52.4 \mathrm{aA}$ & $49.7 \mathrm{aA}$ & 13.1 & $47.7 \mathrm{aA}$ & $47.7 \mathrm{aA}$ & 6.2 \\
\hline CV (\%) & & 8.5 & 9.2 & - & 5.4 & 7.1 & - \\
\hline Flowering & Residual P $\left(\mathrm{P}_{\mathrm{RES}}\right)$ & $181.6 \mathrm{bA}$ & $250.3 \mathrm{aA}$ & 8.7 & $164.2 \mathrm{aA}$ & $159.1 \mathrm{aA}$ & 14.9 \\
\hline Veraison & Residual P $\left(\mathrm{P}_{\mathrm{RES}}\right)$ & $75.1 \mathrm{aB}$ & $89.8 \mathrm{aB}$ & 11.4 & $71.9 \mathrm{aB}$ & $86.0 \mathrm{aB}$ & 10.7 \\
\hline $\mathrm{CV}(\%)$ & & 12.1 & 12.9 & - & 9.4 & 8.2 & - \\
\hline Flowering & Total P $\left(\mathrm{P}_{\text {TOTAL }}\right)$ & $4,866.5 \mathrm{aA}$ & 5,103.6aA & 10.2 & $3,512.3 \mathrm{bA}$ & $4,377.5 \mathrm{aA}$ & 14.4 \\
\hline Veraison & Total P $\left(\mathrm{P}_{\text {TOTAL }}\right)$ & $2,956.0 \mathrm{aB}$ & $3,160.5 \mathrm{aB}$ & 8.4 & $3,013.1 \mathrm{aA}$ & $3,260.4 \mathrm{aB}$ & 16.1 \\
\hline CV (\%) & & 10.8 & 11.3 & - & 12.6 & 13.9 & - \\
\hline
\end{tabular}

(1)Means followed by equal letters, lowercase in the lines of the same experiment and uppercase in the columns of the same P form, did not differ by the Scott-Knott test, at $5 \%$ probability. ${ }^{(2)} \mathrm{V} 1$, vineyard 1 of 'Tannat' grapes $\left(11.8 \mathrm{mg} \mathrm{P} \mathrm{kg}^{-1}\right) .{ }^{(3)} \mathrm{V} 2$, vineyard 2 of 'Tannat' grapes $\left(34.6 \mathrm{mg} \mathrm{P} \mathrm{kg}^{-1}\right) .{ }^{(4)} \mathrm{V} 1$, vineyard 1 of 'Cabernet Franc' grapes (16 mg P kg $\left.{ }^{-1}\right) .{ }^{(5)} \mathrm{V} 2$, vineyard 2 of 'Cabernet Franc' grapes $\left(37 \mathrm{mg} \mathrm{P} \mathrm{kg}^{-1}\right)$. CV, coefficient of variation. 
degraded and used as an energy source, supplying the plant requirements for this nutrient.

In the experiment 1 , the principal component analysis (PCA) conducted between $\mathrm{P}$ forms in leaves collected at FL, and yield and must composition, was able to show $76.7 \%$ of the total variation of the results, in the first two ordination axes (Figure 1 A). PCA showed that no $\mathrm{P}$ form was related to yield. The $\mathrm{P}_{\text {TотаL }}$ content and $\mathrm{P}_{\mathrm{SO}}, \mathrm{P}_{\mathrm{LIP}}, \mathrm{P}_{\mathrm{DNA}}$, and $\mathrm{P}_{\mathrm{RES}}$ forms showed a positive correlation with the values of $\mathrm{PP}, \mathrm{AC}, \mathrm{pH}$ and TSS in the must. A negative correlation was observed between $\mathrm{pH}$ and TA in the must, and a positive correlation was verified between TA and $\mathrm{P}_{\mathrm{SI}}$. In the experiment 2 , PCA conducted with the values of $\mathrm{P}$ forms obtained from
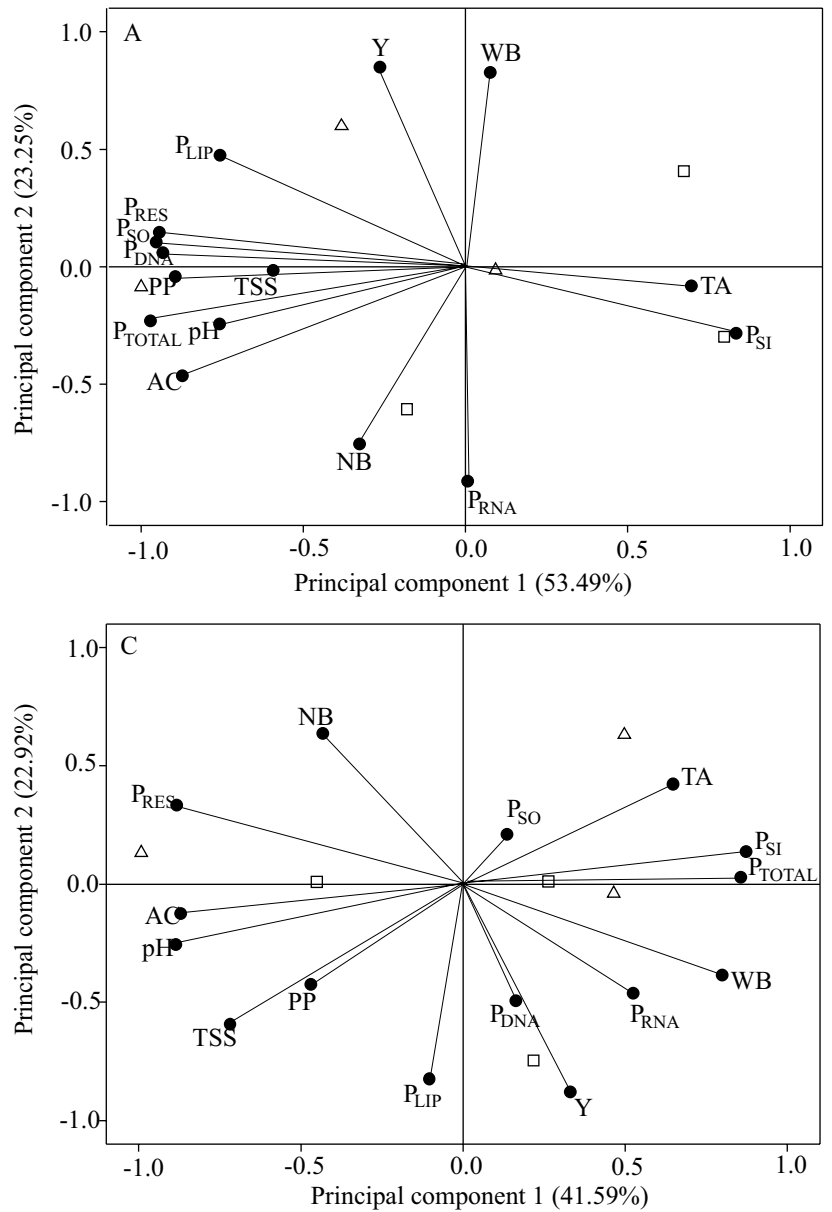

leaves collected at FL, with yield and must composition, was able to show $64.4 \%$ of the total variation of the results in the first two ordination axes (Figure $1 \mathrm{~B}$ ). PCA showed a positive correlation between $\mathrm{P}_{\mathrm{SI}}, \mathrm{NB}$, and yield. A positive correlation was found between $\mathrm{P}_{\mathrm{SO}}$ and TSS, between $\mathrm{P}_{\mathrm{RNA}}$ and PP, and between $\mathrm{P}_{\mathrm{TOTAL}}$ content and $\mathrm{AC}$ content in the must. A negative correlation was found between $\mathrm{pH}$ and $\mathrm{TA}$ in the must.

In the experiment 1, PCA conducted between $\mathrm{P}$ forms in leaves collected at $\mathrm{V}$, and yield and must composition, was able to show $64.51 \%$ of the total variation of the results in the first two ordination axes (Figure 1C). A positive correlation was observed between $\mathrm{P}_{\text {TOTAL }}$ content and $\mathrm{P}_{\mathrm{SI}}$ with TA in the must; and between $\mathrm{P}_{\mathrm{DNA}}$
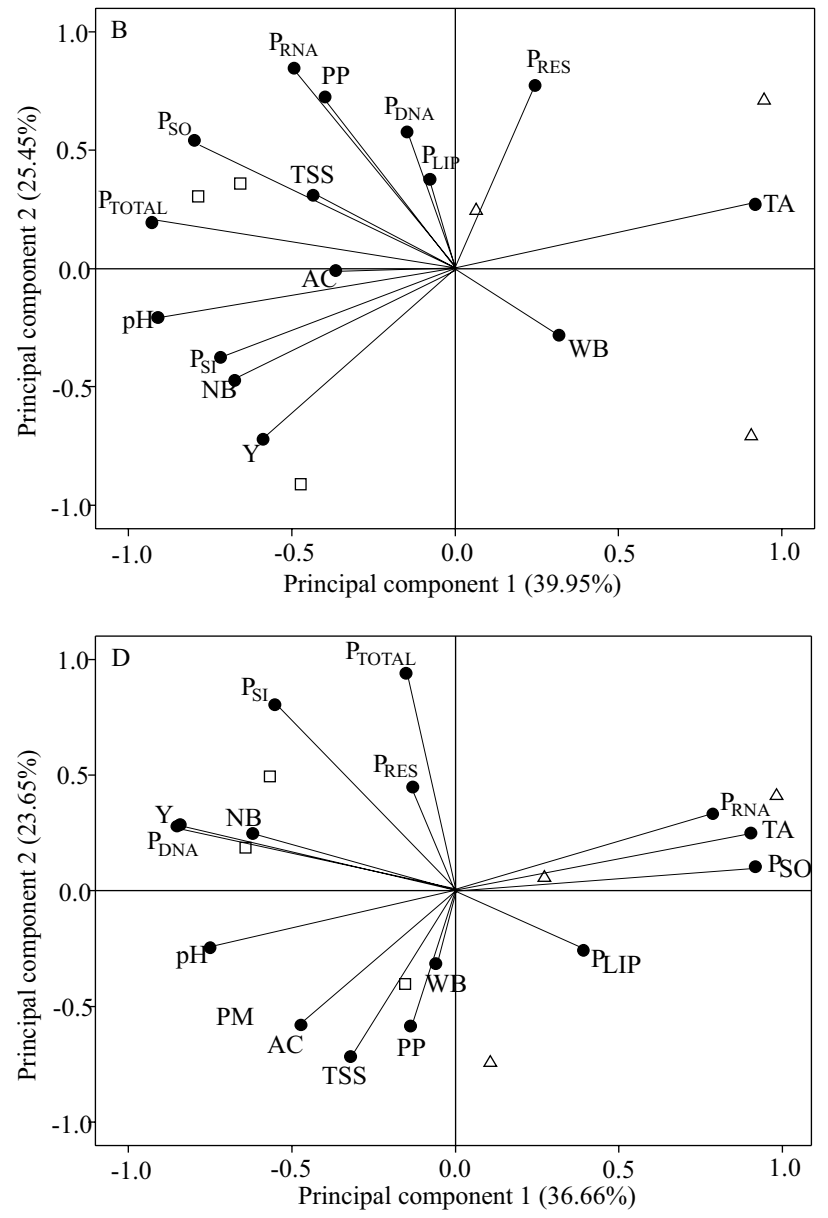

$\square$ Experiment $1 \quad \Delta$ Experiment 2

Figure 1. Projection of the principal components of the contents of available $\mathrm{P}$ in the soil, for the $\mathrm{P}$ forms in leaves, and yield and must composition of experiment 1 ('Tannat' grapes) and experiment 2 ('Cabernet Franc' grapes): A, experiment 1 at flowering; B, experiment 2 at flowering; $\mathrm{C}$, experiment 1 at veraison; and $\mathrm{D}$, experiment 2 at veraison. $\mathrm{P}_{\mathrm{SI}}$, inorganic soluble P; $P_{\mathrm{SO}}$, organic soluble $\mathrm{P}$; $\mathrm{P}_{\mathrm{LIP}}$, lipid $\mathrm{P} ; \mathrm{P}_{\mathrm{RNA}}, \mathrm{P}$ associated with RNA; $\mathrm{P}_{\mathrm{DNA}}, \mathrm{P}$ associated with DNA; $\mathrm{P}_{\mathrm{RES}}$, residual $\mathrm{P} ; \mathrm{P}_{\mathrm{TOTAL}}$, total P; NB, number of berries per cluster; WB, weight of 100 berries; Y, yield; $\mathrm{pH}$; TSS, total soluble solids; TA, titratable acidity; PP, total polyphenols; and $\mathrm{AC}$, anthocyanins. 
and yield. Other must parameters and $\mathrm{P}$ forms were not correlated. In the experiment 2, PCA conducted between $\mathrm{P}$ forms in leaves collected at $\mathrm{V}$, and yield and must composition was able to show $60.31 \%$ of the total variation, in the first two ordination axes (Figure $1 \mathrm{D}$ ). Principal component 1 (36.66\%) was able to separate the two vineyards as for $\mathrm{P}$ content in the soil. There was a positive correlation between $\mathrm{P}_{\mathrm{SO}}$ and $\mathrm{P}_{\mathrm{RNA}}$ forms with $\mathrm{TA}$ in the must; and between $\mathrm{P}_{\mathrm{DNA}}$ with yield and NB. Other must parameters and $\mathrm{P}$ forms were not correlated.

The lack of a positive correlation between yield of the V1 and V2 grapevines of the experiment 1, with the $\mathrm{P}_{\text {TотаL }}$ content in leaves collected at FL and $\mathrm{V}$ may have occurred because there was no significant difference between $\mathrm{P}_{\text {TOTAL }}$ content in leaves of grapevines grown
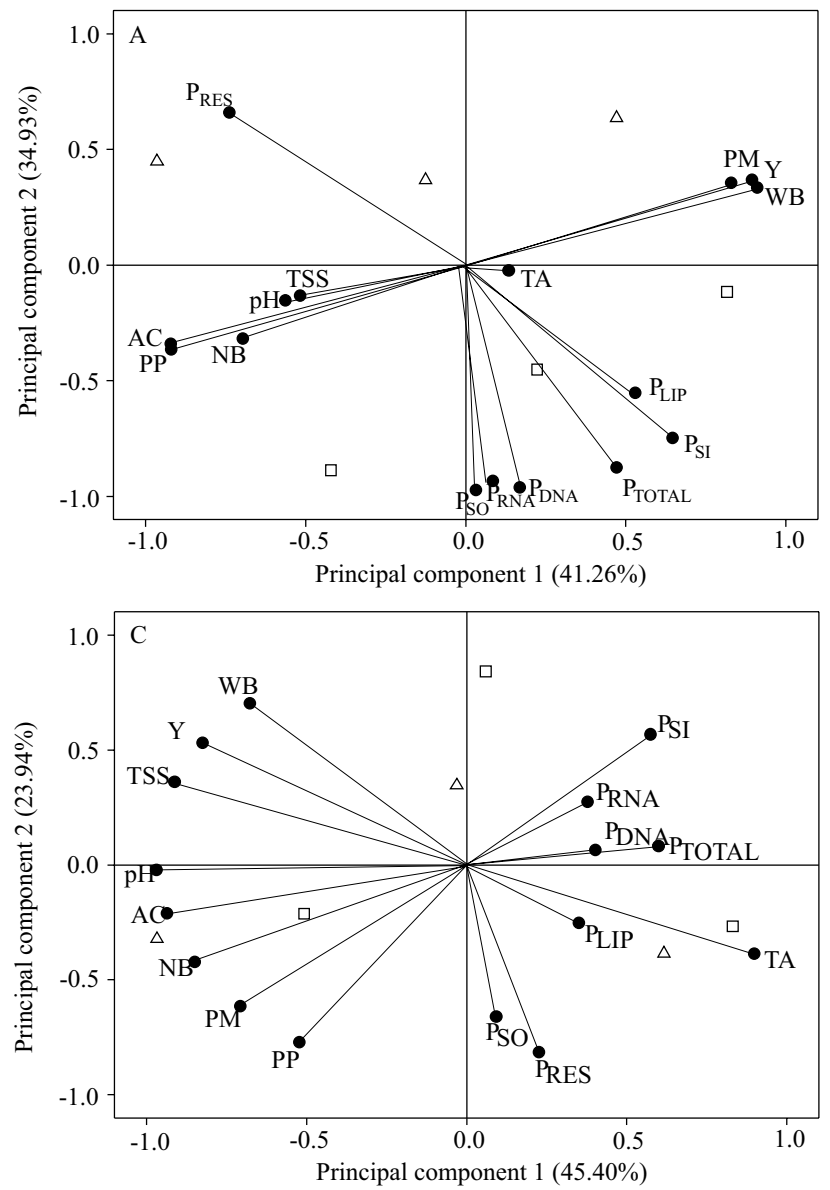

with low and high $\mathrm{P}$ content available in the soil (Table 3). These results show that regardless of the $\mathrm{P}$ content available in the soil and the phenological stage (FL or $\mathrm{V}$ ), $\mathrm{P}_{\text {TотаL }}$ content in full leaves cannot always be used to diagnose $\mathrm{P}$ content available in soil and, therefore, cannot be a good indicator of the nutritional status of grapevines (Brunetto et al., 2009). Furthermore, the lack of response can be attributed to the accumulation of $\mathrm{P}$ in storage organs, such as roots, which can be redistributed in periods of greater demand (Lima et al., 2011).

The principal compoment analysis of the experiment 1, conducted between $\mathrm{P}$ forms in leaves collected at FL and $\mathrm{V}$, in the $\mathrm{V} 1$ (low in soil available P), and yield and must composition, was able to show $76.19 \%$ of the
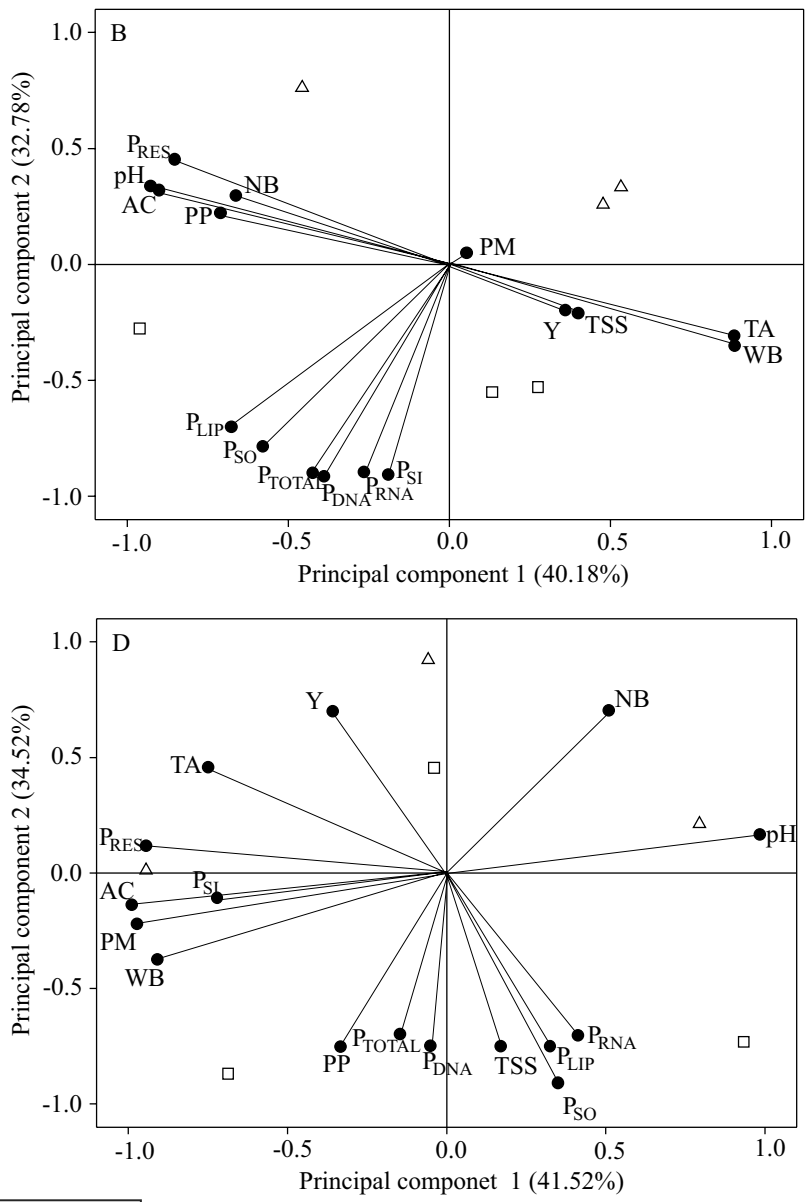

$\triangle$ Flowering $\square$ Veraison

Figure 2. Projection of the main components of $\mathrm{P}$ forms in leaves collected during flowering and veraison, and yield and must composition of two vineayards with 'Tannat' grapes (V1 and V2, experiment 1), and two vineyards of 'Cabernet Franc' grapes (V1 and V2, experiment 2): A, experiment 1, V1; B, experiment 1, V2; C, experiment 2, V1; and D, experiment 2, V2. $\mathrm{P}_{\mathrm{SI}}$, inorganic soluble $\mathrm{P} ; \mathrm{P}_{\mathrm{SO}}$, organic soluble $\mathrm{P} ; \mathrm{P}_{\mathrm{LIP}}$, lipid $\mathrm{P} ; \mathrm{P}_{\mathrm{RNA}}, \mathrm{P}$ associated with RNA; $\mathrm{P}_{\mathrm{DNA}}, \mathrm{P}$ associated with DNA; $\mathrm{P}_{\mathrm{RES}}$, residual P; $\mathrm{P}_{\text {тотАL }}$, total $\mathrm{P}$; NB, number of berries per cluster; $\mathrm{WB}$, weight of 100 berries; Y, yield; $\mathrm{pH}$; TSS, total soluble solids; TA, titratable acidity; PP, total polyphenols; and AC, anthocyanins. 
total variation of the results, in the first two ordination axes (Figure 2A). However, we noted that neither P forms in leaves nor $\mathrm{P}_{\text {TOтАL }}$ content showed any positive correlation with yield and must composition. The PCA of the experiment 1, conducted between $\mathrm{P}$ forms in leaves collected at FL and V, in the V2 (high content of soil available $\mathrm{P}$ ), and yield and must composition, was able to show $72.96 \%$ of the total variation of the results, in the first two ordination axes (Figure $2 \mathrm{~B}$ ). A positive correlation between $\mathrm{P}_{\mathrm{RES}}$ and $\mathrm{NB}$, as well as contents of $\mathrm{PP}, \mathrm{AC}$, and $\mathrm{pH}$ in the must was observed.

The principal componente analysis of the experiment 2, conducted between $\mathrm{P}$ forms in leaves collected at FL and $\mathrm{V}$, with yield and must composition, was able to show $69.34 \%$ and $76.04 \%$ of the total variation of the results, in the first two ordination axes, in V1 and V2, respectively (Figures $2 \mathrm{C}$ and D). In the $\mathrm{V} 1$, there was a relationship between $\mathrm{P}_{\text {LIP }}$ and TA in the must; however, $\mathrm{P}_{\text {TOTAL }}$ content and $\mathrm{P}_{\mathrm{SI}}, \mathrm{P}_{\mathrm{SO}}, \mathrm{P}_{\mathrm{RNA}}$ and $\mathrm{P}_{\mathrm{DNA}}$ in the leaves were not correlated with yield and must composition (Figure $2 \mathrm{C}$ ). In the V2, there was a positive relationship between the following parameters: $\mathrm{P}_{\text {TOTAL }}$ content and $\mathrm{P}_{\mathrm{DNA}}$ with PP content in the must; $\mathrm{P}_{\mathrm{SO}}, \mathrm{P}_{\mathrm{LIP}}$, and $\mathrm{P}_{\mathrm{RNA}}$ with TSS; and $\mathrm{P}_{\mathrm{SI}}$ with $\mathrm{PM}, \mathrm{WB}$, and $\mathrm{AC}$ (Figure $2 \mathrm{D}$ ). The correlation between $\mathrm{P}_{\text {TOTAL }}$ content in leaves and $\mathrm{AC}$ in the must can be explained by the fact that high $\mathrm{P}$ content in the soil and later in plant organs can inhibit enzyme activities, such as chalcone synthase and phenylalanine ammonia-lyase (Hilbert et al., 2003). The negative correlation observed between $\mathrm{pH}$ and TA in the must of grapevines of both vineyards, in both experiments, can be explained by the decrease of the concentration of organic acid (such as tartaric acid), since its concentration can be decreased because of precipitation of $\mathrm{K}$ tartrate and $\mathrm{Ca}$ tartrate (Silva et al., 2015).

\section{Conclusions}

1. Total $\mathrm{P}$ content and biochemical $\mathrm{P}$ forms in leaves, collected during flowering and veraison, have no relationship with yield of 'Tannat' and 'Cabernet Franc' grapevines.

2. The increase of $P$ content available in sandy soil increased the yield of 'Tannat' and 'Cabernet Franc' grapevines, as well as the total polyphenols and anthocyanins in 'Tannat' grapevines.
3. Leaves of 'Cabernet Franc' grapevines, grown in soil with high available $P$ content, accumulated a higher content of total $\mathrm{P}$, as well as organic and inorganic soluble $\mathrm{P}$, during the flowering, and inorganic soluble $\mathrm{P}$, during the veraison.

4. Total $\mathrm{P}$ content and biochemical $\mathrm{P}$ forms, in leaves collected during flowering and veraison, have no relationship with yield of 'Tannat' and 'Cabernet Franc' grapevines.

\section{Acknowledgments}

To Conselho Nacional de Desenvolvimento Científico e Tecnológico $(\mathrm{CNPq})$, for the research productivity scholarships; and to Coordenação de Aperfeiçoamento de Pessoal de Nível Superior (Capes), for the scholarships granted.

\section{References}

BAILLOD, M.; BAGGIOLINI, M. Les stades repères de la vigne. Revue Suisse de Viticulture Horticulture, v.25, p.7-9, 1993.

BATISTA, M.A.V.; PRADO, R. de M.; LEITE, G.A. Resposta de mudas de goiabeira a aplicação de fósforo. Bioscience Journal, v.27, p.635-641, 2011.

BRUNETTO, G.; CERETTA, C.A.; KAMINSKI, J.; MELO, G.W. de; GIROTTO, E.; TRENTIN, E.E.; LOURENZI, C.R.; VIEIRA, R.C.B.; GATIBONI, L.C. Produção e composição química da uva em videiras Cabernet Sauvignon submetidas à adubação nitrogenada. Ciência Rural, v.39, p.2035-2041, 2009. DOI: $10.1590 / \mathrm{S} 0103-84782009005000162$.

BRUNETTO, G.; LORENSINI, F.; CERETTA, C.A.; GATIBONI, L.C.; TRENTIN, G.; GIROTTO, E.; MIOTTO, A.; LOURENZI, C.R.; MELO, G.W. de. Soil phosphorus fractions in a sandy Typic Hapludaft as affected by phosphorus fertilization and grapevine cultivation period. Communications in Soil Science and Plant Analysis, v.44, p.1937-1950, 2013. DOI: 10.1080/00103624.2013.794819.

BRUNETTO, G.; MELO, G.W.B. de; TOSELLI, M.; QUARTIERI, M.; TAGLIAVINI, M. The role of mineral nutrition on yields and fruit quality in grapevine, pear and apple. Revista Brasileira de Fruticultura, v. 37, p.1089-1104, 2015. DOI: 10.1590/0100-2945103/15.

CASALI, C.A.; KAMINSKI, J. ARBUGERI, F.E.; PICCIN, R.; DONEDA, A. Mineralização das formas de fósforo do tecido de plantas de cobertura. Informações Agronômicas, n.135, p.21-24, 2011.

HILBERT, G.; SOYER, J.P.; MOLOT, C.; GIRAUDON, J.; MILIAN, S.; GAUDILLERE, J.P. Effects of nitrogen supply on must quality and anthocyanin accumulation in berries of $\mathrm{cv}$. Merlot. Vitis, v.42, p.69-76, 2003. 
LIMA, R.L.S. de; SEVERINO, L.S; CAZETTA, J.O.; AZEVEDO, C.A.V. de; SOFIATTI, V.; ARRIEL, N.H.C. Redistribuição de nutrientes em folhas de pinhão-manso entre estádios fenológicos. Revista Brasileira de Engenharia Agrícola e Ambiental, v.15, p.1175-1179, 2011. DOI: 10.1590/S1415-43662011001100010.

LORENSINI, F.; CERETTA, C.A.; LOURENZI, C.R.; DE CONTI, L.; TIECHER, T.L.; TRENTIN, G.; BRUNETTO, G. Nitrogen fertilization of Cabernet Sauvignon grapevines: yield, total nitrogen content in the leaves and must composition. Acta Scientiarum. Agronomy, v.37, p.321-329, 2015. DOI: 10.4025/ actasciagron.v37i3.19354.

MURPHY, J.; RILEY, J.P. A modified single solution methods for the determination of phosphate in natural waters. Analytica Chimica Acta, v.27, p.31-36, 1962. DOI: 10.1016/S00032670(00)88444-5.

NOACK, S.R.; MCLAUGHLIN, M.J.; SMERNIK, R.J.; MCBEATH, T.M.; ARMSTRONG, R.D. Phosphorus speciation in mature wheat and canola plants as affected by phosphorus supply. Plant and Soil, v.378, p.125-137, 2014. DOI: 10.1007/ s11104-013-2015-3.

OZDEMIR, G.; AKPINAR, C.; SABIR, A.; BILIR, H.; TANGOLAR, S.; ORTAS, I. Effect of inoculation with mycorrhizal fungi on growth and nutrient uptake of grapevine genotypes (Vitis spp.). European Journal of Horticultural Science, v.75, p.103-110, 2010.

SANTOS, H.G. dos; JACOMINE, P.K.T.; ANJOS, L.H.C. dos; OLIVEIRA, V.A. de; LUMBRERAS, J.F.; COELHO, M.R.; ALMEIDA, J.A. de; CUNHA, T.J.F.; OLIVEIRA, J.B. de. Sistema brasileiro de classificação de solos. 3.ed. rev. e ampl. Brasília: Embrapa, 2013. 353p.

SATO, A.J.; JUBILEU, B. da S.; ASSIS, A.M. de; ROBERTO, S.R. Fenologia, produção e composição do mosto da 'Cabernet Sauvignon' e 'Tannat' em clima subtropical. Revista Brasileira de Fruticultura, v.33, p.491-499, 2011. DOI: 10.1590/S010029452011005000079.

SCHMITT, D.E.; GATIBONI, L.C.; GIROTTO, E.; LORENSINI, F.; MELO, G.W.B.; BRUNETTO, G. Phosphorus fractions in the vineyard soil of the Serra Gaúcha of Rio Grande do Sul, Brazil. Revista Brasileira de Engenharia Agrícola e Ambiental, v.18, p.133-140, 2014. DOI: 10.1590/S1415-43662014000200002.

SILVA, M.J.R. da; TECCHIO, M.A; MOURA, M.F.; BRUNELLI, L.T.; IMAIZUMI, V.M.; VENTURINI FILHO, W.G. Composição físico-química do mosto e do vinho branco de cultivares de videiras em resposta a porta-enxertos. Pesquisa Agropecuária
Brasielira, v.50, p.1105-1113, 2015. DOI: 10.1590/S0100204X2015001100014.

SINGLETON, V.L.; ROSSI JR, J.A. Colorimetry of total phenolics with phosphomolybdic-phosphotungstic acid reagent. American Journal of Enology and Viticulture, v.16, p.144-158, 1965.

SOIL SURVEY STAFF. Keys to soil taxonomy. $11^{\text {th }}$ ed. Washington: Usda, 2010. 338p.

TECCHIO, M.A.; PAIOLI-PIRES, E.J.; TERRA, M.M.; GRASSI FILHO, H.; CORRÊA, J.C.; VIEIRA, C.R.Y.I. Correlação entre a produtividade e os resultados de análise foliar e de solo em vinhedos de Niagara Rosada. Ciência e Agrotecnologia, v.30, p.1056-1064, 2006. DOI: 10.1590/S1413-70542006000600002.

TECCHIO, M.A.; PAIOLI-PIRES, E.J.; TERRA, M.M.; MOURA, M.F. Produtividade e teores de nutrientes da videira 'Niagara Rosada' em vinhedos nos municípios de Louveira e Jundiaí. Bioscience Journal, v.23, p.48-58, 2007.

TEDESCO, M.J.; GIANELLO, C.; ANGHINONI, I.; BISSANI, C.A.; CAMARGO, F.A.O.; WIETHÖLTER, S. (Ed.). Manual de adubação e calagem para os estados do Rio Grande do Sul e de Santa Catarina. Porto Alegre: Sociedade Brasileira de Ciência do Solo, Núcleo Regional Sul, 2004. 400p.

TEDESCO, M.J.; GIANELLO, C.; BISSANI, C.A.; BOHNEN, H.; VOLKWEISS, S.J. Análises de solo, plantas e outros materiais. 2.ed. rev. e atual. Porto Alegre: UFRGS, 1995. 174p. (UFRGS. Boletim técnico, 5).

TEIXEIRA, L.A.J.; QUAGGIO, J.A.; ZAMBROSI, F.C.B. Preliminary DRIS norms for 'Smooth Cayenne' pineapple and derivation of critical levels of leaf nutrient concentrations. Acta Horticulturae, v. 822, p.131-138, 2009.

VANCE, C.P.; UHDE-STONE, C.; ALLAN, D.L. Phosphorus acquisition and use: critical adaptations by plants for securing a nonrenewable resource. New phytologist, v.157, p.423-447, 2003. DOI: 10.1046/j.1469-8137.2003.00695.x.

VENEKLAAS, E.J.; LAMBERS, H.; BRAGG, J.; FINNEGAN, P.M.; LOVELOCK, C.E.; PLAXTON, W.C.; PRICE, C.A.; SCHEIBLE, W.-R.; SHANE, M.W.; WHITE, P.J.; RAVEN, J.A. Opportunities for improving phosphorus-use efficiency in crop plants. New Phytologist, v.195, p.306-320, 2012. DOI: 10.1111/j.1469-8137.2012.04190.x.

ZAMBROSI, F.C.B.; MATTOS JR., D.; BOARETTO, R.M.; QUAGGIO, J.A.; MURAOKA, T.; SYVERTSEN, J.P. Contribution of phosphorus $\left({ }^{32} \mathrm{P}\right)$ absorption and remobilization for citrus growth. Plant and Soil, v.355, p.353-362, 2012. DOI: 10.1007/s11104-011-1107-1.

Received on November 22, 2016 and accepted on February 21, 2017 